\title{
Enrichment of stable carbon and nitrogen isotopes of plant populations and plateau pikas along altitudes
}

\author{
X.F. Yi ${ }^{1,2,3}$ and Y.Q. Yang ${ }^{1}$ \\ ${ }^{1}$ College of Agriculture, Henan University of Science and Technology \\ Luoyang, 471003, P.R. China \\ ${ }^{2}$ Northwest Institute of Plateau Biology, Chinese Academy of Sciences (CAS) \\ 59\#, Xiguan Street, Xining 810001, Qinghai, P.R. China
}

(Received 5 March 2006; revised version 3 August 2006; accepted 6 November 2006)

\begin{abstract}
Stable carbon and nitrogen isotope ratios were measured in plant populations and plateau pikas to determine enrichment in stable isotopes of three alpine meadow ecosystems at different elevations in the Qinghai-Tibet Plateau. The results indicated that stable carbon isotope signatures of plant populations at the three locations showed significant variations, $\delta^{13} \mathrm{C}$ of plant populations showed an enrichment of $0.86 \%$ per $1000 \mathrm{~m}$ over the linear proportion of the altitudinal response, while stable nitrogen isotopes showed no apparent difference. The stable nitrogen isotopes of plateau pikas became significantly isotopically heavier along altitudinal gradients and showed an enrichment of $3.17 \% / \mathrm{km}$. Stable carbon isotopes showed no significance, however, and the enrichment of $0.448 \% / \mathrm{km} . \delta{ }^{13} \mathrm{C}$ and $\delta{ }^{15} \mathrm{~N}$ in plateau pikas were not significantly correlated. There appeared to be segregation between the metabolism of stable carbon and nitrogen isotopes of plateau pikas. Variances in metabolic rate at lower water availability and temperatures are presumed to be the main cause of enrichment of stable nitrogen isotopes along altitudinal gradients. Attention should be paid to construct trophic positions and to trace food chain information based on an isotopic enrichment model.
\end{abstract}

KEY WORDS: stable carbon isotope, stable nitrogen isotope, plateau pikas, altitudinal gradients, Qinghai-Tibet Plateau

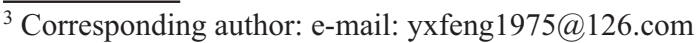




\section{INTRODUCTION}

Fractionation and enrichment of stable isotopes of consumers can be related to the isotopic patterns of the plant populations eaten. Stable isotopic signatures of plants are usually affected by environmental factors and show significant variation along environmental gradients, in which temperature plays a key role (Korner et al., 1988). Although enrichment of stable isotopes of plants along altitudinal gradients has been actively investigated (Guillemette and Stephen, 2001), there are few reports describing the effect on consumers (Hobson et al., 2001; Graves et al., 2002). Furthermore, the large variance in their data unexplained by altitude clearly raises questions as to how useful the stable isotope approach might be in altitudinal investigations on small mammals, especially for the aboriginal small mammal in the Qinghai-Tibet Plateau, plateau pikas. Clearly, more investigations are required in other systems, over large elevational gradients and using other isotopes and tests. Plateau pika (Ochotona curzoniae) is a unique species and has become accustomed to the Qinghai-Tibet Plateau. It is a keystone species of the Qinghai-Tibet Plateau and is always treated as a model species for various studies. Furthermore, plateau pikas are indispensable to the preservation of native biodiversity and the normal functioning of the Qinghai-Tibet Plateau ecosystem. In this study, we focused on variations of stable carbon and nitrogen isotopes of plant populations as well as plateau pikas to: 1 . discuss how the metabolisms of stable carbon and nitrogen isotopes are correlated, 2. determine what is responsible for the isotopic fractionation of plateau pikas along altitudinal gradients, and 3 . what attention should be focused on analysing ecosystem trophic relationships and feed web structure based on stable carbon and nitrogen isotopes.

\section{MATERIAL AND METHODS}

\section{Study areas}

This study was carried out in the Qinghai-Tibet Plateau region in three areas with different elevations, namely, Menyuan county, Henan county, and Maduo county. Menyuan county is located in a large valley oriented NW-SE surrounded on all sides by the Qilian Mountains with N latitude $37^{\circ} 29^{\prime}-37^{\circ} 45^{\prime}$ and E longitude $101^{\circ} 12^{\prime}$ $101^{\circ} 33^{\prime}$. The average altitude is $3250 \mathrm{~m}$ for the valley area. The climate is dominated by the Southeast monsoon and the higher-pressure system of Siberia. The average air temperature is $-1.7^{\circ} \mathrm{C}$ with extreme maximum of $27.6^{\circ} \mathrm{C}$ and minimum $-37.1^{\circ} \mathrm{C}$. Average annual precipitation ranges from 426 to $860 \mathrm{~mm}$ and evaporation averages $1235.6 \mathrm{~mm}$. Vegetation is characterized by alpine shrub, alpine meadow and swamp 
meadow. Henan county is located in the southeast of Qinghai province with an average elevation of $3600 \mathrm{~m}$. The average air temperature is $10.4^{\circ} \mathrm{C}$. Average annual precipitation stands at $606.3 \mathrm{~mm}$ and annual evaporation is $1249.7 \mathrm{~mm}$. Maduo county $\left(\mathrm{E} 97^{\circ} 54^{\prime}-120^{\circ} 50^{\prime}\right.$, E $\left.32^{\circ} 31^{\prime}-35^{\circ} 40^{\prime}\right)$ is also located in the southwest of Qinghai province with an average altitude of $4300 \mathrm{~m}$. The average air temperature is $-4.3^{\circ} \mathrm{C}$ with extreme maximum of $7.3^{\circ} \mathrm{C}$ and minimum $-48^{\circ} \mathrm{C}$. Average annual precipitation stands at $307 \mathrm{~mm}$ and evaporation, at $1264 \mathrm{~mm}$.

\section{Measurement of stable carbon and nitrogen isotopes}

Intact leaves of common plant species (Kobresia humilis, Saussurea superba, Ajania tenuifolia, Leontopodium nanum, Gentiana straminea, Poa annua, Elymus nutans, Oxytropis ochrocephala, Potentilla anserina, Pedicularis longiflora) and back leg muscles of plateau pikas (Ochotona curzoniae) were collected in July 2003. Eight to ten leaves of each species were rinsed with distilled water and mixed, then air dried indoors in an oven to a constant weight at $70^{\circ} \mathrm{C}$ for $48 \mathrm{~h}$, ground finely, and placed in an isotope ratio spectrometer under EAMS (element-analysis meter and spectrometer) conditions. The resulting $\mathrm{CO}_{2}$ and $\mathrm{N}_{2}$ were purified in a vacuum line and injected into a Finnigan MAT DELTA ${ }^{\text {PLUS XL }}$ spectrometer (Finnegan Mat, Bermen, Germany) fitted with double inlet and collector systems. The results are expressed in $\delta^{13} \mathrm{C}$ and $\delta^{15} \mathrm{~N}$ relative to the standards in the conventional $\delta$ per mil notation as follows:

$$
\begin{aligned}
& \delta^{13} \mathrm{C}=\left[\left({ }^{13} \mathrm{C} /{ }^{12} \mathrm{C}\right)_{\text {sample }} /\left({ }^{13} \mathrm{C} /{ }^{12} \mathrm{C}\right)_{\text {standard }^{-1}}\right] \times 1000 \\
& \delta^{15} \mathrm{~N}=\left[\left({ }^{15} \mathrm{~N} /{ }^{14} \mathrm{~N}\right)_{\text {sample }} /\left({ }^{15} \mathrm{~N} /{ }^{14} \mathrm{~N}\right)_{\text {standard }^{-1}}\right] \times 1000
\end{aligned}
$$

where ${ }^{15} \mathrm{~N} /{ }^{14} \mathrm{~N}$ are the isotopic ratios of sample and standard (atmospheric nitrogen); ${ }^{13} \mathrm{C} /{ }^{12} \mathrm{C}$ are the isotopic ratios of sample and PDB (Peedee Belemnite formation from South Carolina, USA.) standard. The overall analytical precision is $\pm 0.2 \%$.

\section{Statistical analysis}

All the data were analysed using SPSS (Statistical Package for Social Scientists) for windows 11.0. Data were expressed as mean \pm SD. Stable carbon and nitrogen isotope ratios were determined if there were significant differences along altitudinal gradients by Independent-Samples T Test (Levene's test). All tests were two-tailed. Statistical results were regarded as significant at the $\mathrm{P}<0.05$ or 0.01 level. 


\section{RESULTS AND ANALYSIS}

The results indicated that stable carbon isotopes of plant species became isotopically heavier along altitudinal gradients, which increased from $-27.81 \pm 0.78 \%$ o at Menyuan county to $-26.99 \pm 0.62 \%$ at Maduo county $\left(P_{\text {Menyuan-Henan }}=0.008\right.$; $\left.P_{\text {Menyuan-Maduo }}=0.161 ; P_{\text {Henan-Maduo }}=0.000\right)$. The stable nitrogen isotope, however, showed no significant variation (Table 1). Stable carbon isotopes of plateau pikas showed a slight enrichment along altitudinal gradients, however, stable nitrogen isotopes demonstrated significant variations from $3.21 \pm 0.18 \%$ o to $6.54 \pm 0.53 \%$ o $\left(P_{\text {Menyuan-Henan }}=0.995 ; P_{\text {Menyuan-Maduo }}=0.000 ; P_{\text {Henan-Maduo }}=0.000\right)$.

Table 1. Patterns of stable carbon and nitrogen isotope ratios of plant population, plateau pikas and their faeces at the three areas with different altitudes ${ }^{1}$

\begin{tabular}{|c|c|c|c|c|c|c|}
\hline \multirow{3}{*}{ Items } & \multicolumn{2}{|c|}{$\begin{array}{c}\text { Menyuan county } \\
\text { Al. } 3250 \mathrm{~m}\end{array}$} & \multicolumn{2}{|c|}{$\begin{array}{c}\text { Hennan county } \\
\text { Al. } 3600 \mathrm{~m}\end{array}$} & \multicolumn{2}{|c|}{$\begin{array}{l}\text { Maduo county } \\
\text { Al. } 4300 \mathrm{~m}\end{array}$} \\
\hline & $\delta^{13} \mathrm{C}$ & $\delta^{15} \mathrm{~N}$ & $\delta^{13} \mathrm{C}$ & $\delta^{15} \mathrm{~N}$ & $\delta^{13} \mathrm{C}$ & $\delta^{15} \mathrm{~N}$ \\
\hline & \multicolumn{6}{|c|}{$\%$} \\
\hline Plant population & $-27.81 \pm 0.78^{\mathrm{a}}$ & $0.44 \pm 0.05^{\mathrm{A}}$ & $-27.24 \pm 0.60^{b}$ & $0.47 \pm 0.07^{\mathrm{A}}$ & $-26.99 \pm 0.62^{b}$ & $0.49 \pm 0.11^{\mathrm{A}}$ \\
\hline Plateau pika & $-24.95 \pm 0.25^{\mathrm{a}}$ & $3.21 \pm 0.18^{\mathrm{A}}$ & $-24.68 \pm 0.08^{\mathrm{a}}$ & $3.21 \pm 0.31^{\mathrm{A}}$ & $-24.10 \pm 0.42^{b}$ & $6.38 \pm 0.43^{\mathrm{B}}$ \\
\hline $\begin{array}{l}\text { Faeces of } \\
\text { plateau pikas }{ }^{2}\end{array}$ & $-30.01 \pm 0.10^{\mathrm{a}}$ & $-1.50 \pm 0.04^{\mathrm{A}}$ & $-30.26 \pm 0.17^{\mathrm{a}}$ & $-1.74 \pm 0.06^{\mathrm{B}}$ & $-30.17 \pm 0.23^{\mathrm{a}}$ & $-3.18 \pm 0.15^{C}$ \\
\hline
\end{tabular}

${ }^{1}$ superscripts with different letters in the same item indicate significant at $\mathrm{P}=0.05$ level

${ }^{2}$ sample sizes for all faeces are 6

\section{DISCUSSION}

Stable isotopes of plants are affected by numerous environmental factors, such as temperature (O'Leary, 1988; Morecroft et al., 1990; Edwards et al., 2000), air pressure (Polley et al., 1995), and precipitation (Rice and Giles, 1996). As a result, the variability in plants causes variations in stable isotope patterns of consumers. Comparison of stable isotopes of plateau pikas living in the three areas indicated that enrichment of stable carbon isotopes along altitudinal gradients was $0.448 \%$ / $\mathrm{km}$, and stable nitrogen isotopes, $3.17 \% / \mathrm{km}$. It was also found that enrichment of stable carbon isotopes of plants was $0.86 \% / \mathrm{km}$, which is in accordance with the results $(0.78 \% \mathrm{o} / \mathrm{km})$ of Korner et al. (1988). This indicates that isotopic enrichment of the plateau pika was not proportional to that of plant populations; variations in environmental factors along altitudinal gradients might played a major role, with low temperature possibly being the main factor. Stable nitrogen isotopes of plants are mainly determined by the nitrogen source in the soil $\left(\mathrm{NO}_{3}^{-}\right.$and $\left.\mathrm{NH}_{4}^{+}\right)$(Shearer et al., 1983). Some $\mathrm{N}_{2}$-fixing plant species are also affected by the isotopic pattern 
of atmospheric $\mathrm{N}_{2}$ (Lajtha and Marshall, 1994). Our study demonstrated that there was no significant difference among stable nitrogen isotopes of plant populations along altitudinal gradients (Table 1), which firmly indicates that variations in isotopic signatures of plant populations were not the main reason for enrichment of stable nitrogen isotopes of plateau pikas. Enrichment of stable nitrogen isotopes of plateau pika originated from fixation of nitrate, ammonium and nitrogen (Schoeninger et al., 1998). Enrichment with stable nitrogen isotopes occurred during digestion, assimilation and excretion. Degradation and assimilation of protein and amino acids as well as excretion of carbamide play a key role in this process (Vander et al., 1975; Eckert et al., 1988). Some studies have demonstrated that water stress resulted in increases in $\delta^{15} \mathrm{~N}$ values (Cormie and Schwarcz, 1996). Heaton (1987) and Shearer and Kohl (1989) found that animals possessed higher $\delta^{15} \mathrm{~N}$ values in dry areas. Based on the above information, we speculated that the enrichment of stable nitrogen isotopes of plateau pikas could be attributed to water stress. The degree, to which nitrogen isotopes are fractionated in the production of nitrogenous waste appears to be related, at least in mammals, to the water stress experienced (Cormie and Schwarcz, 1996). The effect of water stress is thought to contribute to the finding of an inverse relationship between annual rainfall and the $\delta^{15} \mathrm{~N}$ values of consumers' tissues (Cormie and Schwarcz, 1996). A likely explanation for this pattern is that the fractionation of nitrogen isotopes is greater in the production of concentrated nitrogenous waste than in the production of dilute nitrogenous waste, which would result in elevated $\delta^{15} \mathrm{~N}$ values (Cormie and Schwarcz, 1996). Coincidently, our study revealed that faeces of plateau pikas living at higher altitudes possessed significantly lower $\delta^{15} \mathrm{~N}$ values $\left(P_{\text {Menyuan-Henan }}=\right.$ $0.000 ; P_{\text {Menyuan-Maduo }}=0.000 ; P_{\text {Henan-Maduo }}=0.000$ ), which firmly supports the above hypothesis. However, stable carbon isotope of faeces remained constant $\left(P_{\text {Menyuan- }}\right.$ Henan $\left.=0.069 ; P_{\text {Menyuan-Maduo }}=0.614 ; P_{\text {Henan-Maduo }}=0.282\right)$. Furthermore, drastically decreasing precipitation and increasing evaporation along the altitudinal gradients of the three different areas firmly support our hypothesis. On the other hand, nutritional stress can also result in elevation of stable nitrogen isotope ratios (Hobson and Clark, 1992). Based on a series of field experiments, Hobson et al. (1993) proposed that higher stable nitrogen isotopic ratios of birds were closely correlated with nutritional stress. However, Ben-David et al. (1999) found that ${ }^{15} \mathrm{~N}$ signatures do not reflect the body condition in Arctic ground squirrels. In this case, stable nitrogen isotopic patterns of small mammals can reveal their nutritional status. Whether nutritional stresses exist and play a role in elevation of $\delta^{15} \mathrm{~N}$ values or not needs to be further investigated. It is nonetheless reasonable to propose that lower $\delta^{15} \mathrm{~N}$ values in faeces represent a higher assimilation rate, which reflects a high metabolic rate at the higher altitude and lower temperature environments on the plateau. 
In summary, enrichment and fractionation of stable carbon and nitrogen isotopes of plateau pikas can be attributed to the variations in isotopic patterns of plant populations as well as environmental factors (especially water stress and low temperature) along altitudinal gradients. The metabolism of the stable nitrogen isotope of plateau pikas is prone to be influenced by environmental factors, in contrast with the stable carbon isotope. Consequently, there appears to be segregation between the metabolism of stable carbon and nitrogen isotopes of plateau pikas, with stable nitrogen isotope metabolism being highly water- and temperature-dependent in higher altitude areas. Due care should therefore be taken when using stable nitrogen isotope ratios to construct trophic positions and trace food chain information in stressed ecosystems based on isotopic enrichment models. Alternatively, however, stable carbon isotope ratios can be a trustful indicator for trophic positions, because stable carbon isotope metabolism and enrichment of small mammals is only slightly influenced by environmental factors along altitudinal gradients.

\section{ACKNOWLEDGEMENTS}

The authors thank the Haibei Alpine Meadow Ecosystem Research Station for facilitating this research and Henan University of Science and Technology for providing part of the foundation support (No. 2006ZY005 and No. 2004018).

\section{REFERENCES}

Ben-David M., McColl C.J., Boonstra R., Karels T.J., 1999. ${ }^{15} \mathrm{~N}$ signatures do not reflect body condition in Arctic ground squirrels. Can. J. Zool. 77, 1373-1378

Cormie A.P., Schwarcz H.P., 1996. Effects of climate on deer bone $\delta^{15} \mathrm{~N}$ and $\delta^{13} \mathrm{C}$ : lack of precipitation effects on $\delta^{15} \mathrm{~N}$ for animals consuming low amounts of $\mathrm{C}_{4}$ plants. Geochim. Cosmochim. Acta 60, 4161-4166

Eckert R., Randall D., Augustine G. (Editors), 1988. Animal Physiology: Mechanisms and Adaptations. San Francisco Press

Edwards T.W.D., Graf W., Trimborn P., Stichler W., Lipp J., Payer H.D., 2000. $\delta^{13} \mathrm{C}$ response surface resolves humidity and temperature signals in trees. Geochim. Cosmochim. Acta 64, 161-167

Graves G.R., Romanek C.S., Navarro A.R., 2002. Stable isotope signature of philoparty and dispersal in a migratory songbird. Proc. Nat. Acad. Sci. USA 99, 8096-8100

Guillemette M., Stephen J.B., 2001. Carbon isotopes in Ombrogenic peat bog plants as climatic indicators: calibration from and altitudinal transect in Switzerland. Org. Geochem. 32, 233-245

Heaton T.H.E., 1987. The ${ }^{15} \mathrm{~N} /{ }^{14} \mathrm{~N}$ ratios of plants in South Africa and Namibia: relationship to climate and coastal saline environments. Oecologia 74, 236-246

Hobson K.A., Alisauskas R.T., Clark R.G., 1993. Stable nitrogen isotope enrichment in avian tissue due to fasting and nutritional stress: implication for isotopic analyses of diet. Condor 95, 388-394 
Hobson K.A., Clark R.W., 1992. Assessing avian diets using stable isotopes. II. Factors influencing diet-tissue fractionation. Condor 94, 189-197

Hobson K.A., McFarland K.P., Wassenaar L.I., Rimmer C.C., Goetz J.E., 2001. Linking breeding and wintering grounds of Bicknell's thrushes using stable isotope analyses of feathers. Auk 118, $16-23$

Korner C., Farquhar G.D., Roksandic Z., 1988. A global survey of carbon isotope discrimination in plants from high altitude. Oecologia 74, 623-632

Lajtha K., Marshall J.D., 1994. Sources of variation in the stable isotopic composition of plants. In: K. Lajtha, R.H. Michener (Editors). Stable Isotopes in Ecology and Environmental Science. Blackwell Scientific Press, New York, pp. 1-21

Morecroft M.D., Woodward F.I., Marrs R.H., 1990. Experimental investigations on the environmental determination of $\delta^{13} \mathrm{C}$ at different altitudes. J. Exp. Bot. 41, 1303-1308

O’Leary M.H., 1988. Carbon isotopes in photosynthesis. Bioscience 38, 328-336

Polley H.W., Johnson H.B., Mayeux H.S., 1995. Nitrogen and water requirements of $\mathrm{C}_{3}$ plants grown at glacial to present carbon dioxide concentrations. Funct. Ecol. 9, 86-96

Rice S.K., Giles L., 1996. The influence of water content and leaf anatomy on carbon isotope discrimination and photosynthesis in Sphagnum. Plant Cell Environ. 19, 118-124

Schoeninger M.J., Iwaniec U.T., Nash L.T., 1998. Ecological attributes recorded in stable isotope ratios of arboreal prosimian hair. Oecologia 113, 222-230

Shearer G., Kohl D.H., 1989. Estimates of $\mathrm{N}_{2}$ fixation in ecosystems: the need for and basis of the ${ }^{15} \mathrm{~N}$ natural abundance method. In: P.W. Rundel, J.R. Ehleringer, K.A. Nagy (Editors). Stable Isotopes in Ecological Research. Springer-Verlag Press, New York, pp. 342-374

Shearer G., Kohl D.H., Virginia R.A., 1983. Estimates of $\mathrm{N}_{2}$ fixation from variation in the natural abundance of ${ }^{15} \mathrm{~N}$ in Sonoran desert plants. Oecologia 56, 365-373

Vander A.J., Sherman J.N., Luciano D.S. (Editors), 1975. Human Physiology: the Mechanisms of Body Function. McGraw-Hill Book Co. Press 